\title{
Synchaeta jollyae (Shiel \& Koste) (Rotifera, Synchaetidae): an overlooked species or a newcomer in Neotropical freshwaters?
}

\author{
Natalia F. Negreiros ${ }^{1}$, Renata M. dos Santos ${ }^{1}$, Laira Lúcia Damasceno de Oliveira ${ }^{2}$, \\ Maria J. dos Santos-Wisniewski ${ }^{3} \&$ Odete Rocha ${ }^{4}$
}

\footnotetext{
1. Programa de Pós Graduação em Ecologia e Recursos Naturais, Universidade Federal de São Carlos, Rodovia Washington Luis, Km 235, Caixa Postal 676, 13565-905, São Carlos, SP, Brasil. (natalia felix@yahoo.com.br)

2. Programa de Pós Graduação em Ciências da Engenharia Ambiental, Escola de Engenharia de São Carlos, Universidade de São Paulo, Av. Trabalhador Sancarlense, 400, 13566-590, São Carlos, SP, Brasil.

3. Departamento de Biologia, Universidade Federal de Alfenas, Rua Gabriel Monteiro da Silva, 714, 37130-000, Alfenas, MG, Brasil.

4. Departamento de Ecologia e Biologia Evolutiva, Universidade Federal de São Carlos, Rodovia Washington Luis, Km 235, Caixa Postal 676, 13565-905, São Carlos, SP, Brasil.
}

\begin{abstract}
Populations of Synchaeta jollyae (Shiel \& Koste, 1993) (Rotifera), a species recently recorded for the first time in Brazil and South America, were analyzed in reservoirs in Southeast Brazil. Sampling was carried out monthly from August 2006 to July 2007 at Furnas Reservoir in the Rio Grande basin, state of Minas Gerais, and in four cascade reservoirs in the Tietê River basin (Barra Bonita, Bariri, Ibitinga and Nova Avanhandava) state of São Paulo, in June and September 2008 and in January and May 2009. Synchaeta jollyae occurred in most samples and periods. From the results obtained it is evident that $S$. jollyae occurs in water bodies of varied trophic status but reaches larger populations in eutrophic water bodies and during lower temperature periods. The greatest densities of $S$. jollyae were found in the eutrophic Bariri Reservoir, on the Tietê River, during the winter. Mann-Whitney test confirmed the significant difference between the population densities in periods of high and low temperatures, with populations reaching higher densities at lower temperatures. It is not yet possible to tell whether $S$. jollyae is a widely distributed species that has been overlooked in previous plankton studies in South America. Wherever these populations of $S$. jollyae might have originated, it appears to be a species well established and adapted to a wide range of conditions in the Neotropics.
\end{abstract}

KEYWORDS. Zooplankton, rotifers, Furnas Reservoir, Tietê River.

RESUMO. Synchaeta jollyae (Shiel \& Koste, 1993) (Rotifera, Synchaetidae): uma espécie negligenciada ou uma recém-chegada em água doces neotropicais? Populações de Synchaeta jollyae (Rotifera, Synchaetidae), uma espécie recentemente registrada pela primeira vez no Brasil e América do Sul, foram analisadas em reservatórios do Sudeste do Brasil. As amostragens foram realizadas mensalmente de agosto de 2006 a julho de 2007 no Reservatório de Furnas, bacia do rio Grande, estado de Minas Gerais e em quatro reservatórios em cascata na bacia do rio Tietê (Barra Bonita, Bariri, Ibitinga e Nova Avanhandava), estado de São Paulo, em junho e setembro de 2008, e janeiro e maio de 2009. Synchaeta jollyae ocorreu na maioria das amostras e períodos. Pelos resultados obtidos é evidenciado que $S$. jollyae ocorre em corpos d'água com variados graus de trofia, porém atinge maiores densidades em corpos d'água eutróficos e em períodos de temperaturas mais baixas. As maiores densidades foram registradas na bacia do rio Tietê, no reservatório eutrófico de Bariri durante o inverno. O teste de Mann-Whitney evidenciou diferença estatisticamente significante entre as densidades populacionais de $S$. jollyae nos períodos com temperaturas mais baixas e temperaturas altas, com as populações atingindo maiores densidades em temperaturas menores. Ainda não é possível dizer se $S$. jollyae é uma espécie amplamente distribuída e negligenciada em estudos anteriores na região Neotropical ou trata-se de uma espécie recém-chegada. Quaisquer que sejam as origens destas populações de $S$. jollyae, parece ser uma espécie bem estabelecida e adaptada a uma ampla faixa de condições nos neotrópicos.

PALAVRAS-CHAVE. Zooplâncton, rotíferos, reservatório de Furnas, rio Tietê.

Gaps in our knowledge of deficiencies regarding the taxonomy of small invertebrates can impose great limitations on the study of freshwater biodiversity. In some groups such as Protozoa and Rotifera, species are easily overlooked or incorrectly identified. This seems to be the case of the rotifer Synchaeta jollyae (Shiel \& Koste, 1993) (Rotifera, Synchaetidae), first described in Australia by Shiel \& Koste (1993). This species was recently recorded in the Neotropical region (NEGREIROS et al., 2011) and, as originally suggested by SHIEL \& KOSTE (1993), it could have a widespread distribution. Mapping the distribution of newly recorded species is also a tool for tracking the introduction of exotic invasive species, nowadays a priority regarding biodiversity conservation.

Synchaetidae comprises four genera, and Synchaeta is the type. There are 34 known species in this genus and eight species have been recorded in the Neotropical region: Synchaeta arcifera Xu, 1998; S. kitina kitina Rousselet, 1902; S. longipes Gosse, 1887; S. oblonga Tessin, 1890; S. pectinata Ehrenberg, 1832; S. stylata Wierzejski, 1893; S. tremula (O. F. Müller,1786) and the recently included $S$. jollyae.
In this study, the populations of $S$. jollyae in some Southeast Brazilian reservoirs are analyzed regarding temporal occurrence, population abundances and relationships with environmental variables, aiming to provide information on the environments where this species has been found and some population parameters.

\section{METHODS}

Study area. Plankton samples from five large reservoirs in Southern Brazil were analyzed for the presence and density of a Synchaeta jollyae population. The first, Furnas Reservoir, is in the Rio Grande Basin (20 $40^{\prime} \mathrm{S}$, $46^{\circ} 19^{\prime} \mathrm{W}$ ), it is a large reservoir with 17.21 billion $\mathrm{m}^{3}$ volume and $1,440 \mathrm{~km}^{2}$ flooded area (Pinto-Coelho \& Corgosinho, 1998). The other four belong to a cascade of reservoirs on the Tietê River in state of São Paulo: Barra Bonita ( $22^{\circ} 31^{\prime}$ S, $\left.48^{\circ} 31^{\prime} \mathrm{W}\right)$, Bariri $\left(22^{\circ} 09^{\prime} \mathrm{S}, 48^{\circ} 44^{\prime} \mathrm{W}\right)$, Ibitinga $\left(21^{\circ} 45^{\prime} \mathrm{S}\right.$, $\left.48^{\circ} 58^{\prime} \mathrm{W}\right)$ and Nova Avanhandava ( $\left.21^{\circ} 07^{\prime} \mathrm{S}, 50^{\circ} 17^{\prime} \mathrm{W}\right)$.

Sampling was carried out each month from August 2006 to July 2007, at six sites located in the Sapucaí River arm of Furnas reservoir. In the four Tietê 
River reservoirs samples were collected in June and September 2008 and in January and May 2009.

Physical and chemical variables were determined in situ in all the water samples taken from the Furnas and Tietê reservoirs and are listed in Table I, with an indication of the technique employed.

The zooplankton were collected by plankton net of $68 \mu \mathrm{m}$ mesh, preserved in $4 \%$ formaldehyde and stored in polyethylene flasks. Subsamples of $1 \mathrm{~mL}$ were transferred to a Sedgwick-Rafter cell, and Synchaeta jollyae specimens were counted under an optical microscope at up to 200x magnification. The species was identified from descriptions published by SHIEL \& Koste (1993) and Nogrady \& Segers (2002).

Comparisons of Synchaeta jollyae densities between the periods of higher and lower temperatures were performed by the application of the Mann-Whitney test. This analysis was carried out with the program XLSTAT (ADDINSOFT, 2009)
Specimens of Synchaeta jollyae were found in the samples collected in every month, except March and May 2007, and at all six sampling sites in the reservoir. The highest densities occurred at a site near a discharge of domestic wastewater, where a maximum of 3,370 ind $\mathrm{m}^{-3}$ was recorded in June 2007 (Fig. 1)

Mid-Low Tietê River Basin (São Paulo). In the reservoirs of Middle Tietê River, mean values of water temperature ranged from $20.07 \pm 0.05^{\circ} \mathrm{C}$ in Barra Bonita to $26.52 \pm 0.84^{\circ} \mathrm{C}$ in Bariri, with higher values in January and May 2009. The pH ranged from slightly acid to alkaline with readings between $5.44 \pm 0.11$ in Barra Bonita (June 2008) and 7.89 \pm 0.81 in Bariri (January 2009). The concentration of dissolved oxygen in the water column ranged from $0.48 \pm 1.82 \mu \mathrm{g} \mathrm{L}^{-1}$ in Barra Bonita (January 2009 ) to $5.70 \pm 3.82 \mu \mathrm{g} \mathrm{L}^{-1}$ in Ibitinga (June 2008). There was a tendency for higher values of electrical conductivity to be seen in reservoirs during the dry season than during the rainy $\left(100.0\right.$ to $\left.277.0 \mu \mathrm{S} \mathrm{cm}^{-1}\right)$. The mean

Tab. I. Methods used to record or analyze physical and chemical properties of the water at sampling sites in the Furnas reservoir (state of Minas Gerais, Brazil) and those on the Mid-low Tietê River (state of São Paulo, Brazil).

\begin{tabular}{|c|c|c|}
\hline & Reservoir: UHE Furnas & Tietê River Basin \\
\hline Temperature $\left({ }^{\circ} \mathrm{C}\right)$ & Thermometer & multiprobe - HORIBA ${ }^{\circledR}$, U-10 \\
\hline $\mathrm{pH}$ & Digital pHmeter - Quimis & multiprobe - HORIBA ${ }^{\circledR}, \mathrm{U}-10$ \\
\hline Eletrical conductivity $\left(\mu \mathrm{S} . \mathrm{cm}^{-1}\right)$ & Digital conductivity meter - Quimis & multiprobe - HORIBA ${ }^{\circledR}$, U-10 \\
\hline Dissolved oxygen (mg. $\left.\mathrm{L}^{-1}\right)$ & $\begin{array}{l}\text { Winkler method modified with } \mathrm{NaN}_{3} \\
\text { (GolTERMAN et al., 1978) }\end{array}$ & multiprobe - HORIBA ${ }^{\circledR}, \mathrm{U}-10$ \\
\hline Transparency (m) & \multicolumn{2}{|c|}{ Secchi disk } \\
\hline Nutrients (total $\mathrm{P}$ and $\mathrm{N})\left(\mu \mathrm{g} . \mathrm{L}^{-1}\right)$ & \multicolumn{2}{|c|}{ MACKERETH et al. (1978) } \\
\hline Chlorophyll $a$ & \multicolumn{2}{|c|}{ LORENZEN (1966) } \\
\hline Trophic state index (TSI) & \multicolumn{2}{|c|}{ CARLson (1977), modified by Toledo et al. (1983) } \\
\hline
\end{tabular}

\section{RESULTS}

Rio Grande Basin (Minas Gerais). In the period August 2006 to July 2007, during which samples were collected from the Sapucaí River arm in the Furnas reservoir, the well defined climatic seasons were reflected in wide variations in the physical and chemical properties of the water. Temperature varied between $18^{\circ} \mathrm{C}$ and $31^{\circ} \mathrm{C}$, the $\mathrm{pH}$ between slightly acid and alkaline (6.35 to 8.88 ) and the electrical conductivity from 14.7 to $60 \mu \mathrm{S} \mathrm{cm}^{-1}$. The water column transparency ranged from $1.08 \mathrm{~m}$ to $15.6 \mathrm{~m}$ and dissolved oxygen concentrations were high, with mean values over $8.0 \mathrm{mg} \mathrm{L}^{-1}$ (Tab. II).

Regarding nutrient levels, the highest nitrogen and phosphorus contents were recorded in the rainy period (from October to January); the mean total contents for the year of study were $356.62 \mu \mathrm{g} \mathrm{L}^{-1} \pm 202.32 \mu \mathrm{g} \mathrm{L}^{-1}$ for $\mathrm{N}$ and $30.89 \mu \mathrm{g} \mathrm{L}^{-1} \pm 34.57 \mu \mathrm{g} \mathrm{L}^{-1}$ for P. The chlorophyll $a$ levels were low in all months except January, when the mean content was $79.5 \mu \mathrm{g} \mathrm{L}^{-1}$; there was little variation in the other months and the overall mean was $8.5 \pm$ $13.43 \mu \mathrm{g} \mathrm{L}^{-1}$. In general, the calculated TSI showed the Furnas reservoir to be oligotrophic (Tab. II), with a slight tendency to become mesotrophic in some compartments in certain months. concentrations of nitrogen and phosphorus compounds were higher in September 2008 and January 2009, and the mean total content for the year of study was 2000.0 $\mu \mathrm{g} \mathrm{L}^{-1} \pm 690.0 \mu \mathrm{g} \mathrm{L}-1$ for $\mathrm{N}$ and $94.2 \mu \mathrm{g} \mathrm{L}^{-1} \pm 41.8 \mu \mathrm{g} \mathrm{L}^{-1}$ for P in Barra Bonita reservoir. The chlorophyll $a$ values were high in the rainy period and the mean value varied between $0.45 \pm 0.18 \mu \mathrm{g} \mathrm{L}^{-1}$ in May 2009 (Ibitinga) and $29.31 \pm 28.60 \mu \mathrm{g} \mathrm{L}^{-1}$ in January 2009 (Bariri); the overall mean ranged from $10.3 \pm 11.35 \mu \mathrm{g} \mathrm{L}^{-1}$ to $22.7 \pm 31.3 \mu \mathrm{g}$ $\mathrm{L}^{-1}$ (Tab. III). The calculated TSI indicated that the Barra Bonita and Bariri reservoirs were eutrophic and Ibitinga mesotrophic (Tab. III).

The water temperature in the Nova Avanhandava reservoir (Lower Tietê River), mean values varied from $21.85 \pm 0.38^{\circ} \mathrm{C}$ to $26.73 \pm 0.33^{\circ} \mathrm{C}$, with higher values in January and May 2009. The $\mathrm{pH}$ was slightly acid to near neutral, readings ranging from $5.75 \pm 0.31$ in September 2008 to $7.10 \pm 0.23$ in July 2008. The water column of this reservoir generally was well oxygenated, though conditions close to anoxia $\left(0.22 \mathrm{mg} \mathrm{L}^{-1}\right)$ were observed on the bottom in January 2009. Electrical conductivity did not vary greatly, but a small rise in the readings occurred during the rainy period (152.0 to $\left.179.0 \mu \mathrm{S} \mathrm{cm} \mathrm{cm}^{-1}\right)$. In contrast, the mean concentrations of nitrogen and phosphorus compounds exhibited wide variations, with higher values 
Tab. II. Physical, chemical and biological variables (mean \pm standard deviations) in the water at six sites in Furnas reservoir (state of Minas Gerais, Brazil) between August 2006 and July 2007. (Olig, oligotrophic; Temp, temperature; EC, electrical conductivity; DO, dissolved oxygen; Transp, transparency; TN, total nitrogen; TP, total phosphorus; Chl, chlorophyll; TSI, trophic state index).

\begin{tabular}{|c|c|c|c|c|c|c|c|c|c|}
\hline River Compartment & $\begin{array}{l}\text { Temp } \\
\left({ }^{\circ} \mathrm{C}\right)\end{array}$ & $\mathrm{pH}$ & $\begin{array}{c}\text { EC } \\
\left(\mu . \mathrm{cm}^{-1}\right)\end{array}$ & $\begin{array}{c}\text { DO } \\
\left(\mathrm{mg} \cdot \mathrm{L}^{-1}\right)\end{array}$ & Transp (m) & $\begin{array}{c}\mathrm{TN} \\
\left(\mu \mathrm{g} . \mathrm{L}^{-1}\right)\end{array}$ & $\begin{array}{c}\mathrm{TP} \\
\left(\mu \mathrm{g} . \mathrm{L}^{-1}\right)\end{array}$ & $\begin{array}{l}\text { Chl. } a \\
\left(\mu \mathrm{g} . \mathrm{L}^{-1}\right)\end{array}$ & TSI \\
\hline Cabo Verde I & $28.0 \pm 3.8$ & $7.6 \pm 0.9$ & $20.9 \pm 2.5$ & $8.7 \pm 1.2$ & $2.6 \pm 0.8$ & $271.6 \pm 92.0$ & $5.3 \pm 1.9$ & $7.4 \pm 5.3$ & Olig \\
\hline Cabo Verde II & $28.3 \pm 3.4$ & $7.6 \pm 0.7$ & $21.2 \pm 2.1$ & $9.3 \pm 1.8$ & $2.5 \pm 0.8$ & $315.8 \pm 75.6$ & $4.9 \pm 3.1$ & $6.4 \pm 3.5$ & Olig \\
\hline Muzambão & $27.1 \pm 2.9$ & $7.6 \pm 0.8$ & $25.5 \pm 6.9$ & $9.3 \pm 1.5$ & $2.6 \pm 0.9$ & $311.6 \pm 108.1$ & $5.0 \pm 1.5$ & $5.8 \pm 3.0$ & Olig \\
\hline Sapucaí I & $24.9 \pm 2.3$ & $7.2 \pm 0.6$ & $20.5 \pm 4.2$ & $8.4 \pm 0.9$ & $2.6 \pm 1.7$ & $491.8 \pm 266.1$ & $4.9 \pm 2.3$ & $12.7 \pm 22.1$ & Olig \\
\hline Sapucaí II & $24.4 \pm 2.8$ & $7.1 \pm 0.6$ & $19.1 \pm 1.5$ & $8.8 \pm 1.0$ & $2.3 \pm 1.6$ & $505.6 \pm 322.7$ & $4.6 \pm 1.7$ & $8.4 \pm 13.4$ & Olig \\
\hline Confluence & $25.6 \pm 3.0$ & $7.5 \pm 0.7$ & $22.1 \pm 6.3$ & $8.5 \pm 1.4$ & $2.7 \pm 1.4$ & $419.4 \pm 281.5$ & $4.7 \pm 1.9$ & $10.3 \pm 20.6$ & Olig \\
\hline
\end{tabular}

Tab. III. Physical, chemical and biological variables (mean \pm standard deviation) in the water in reservoirs on the Mid-low Tietê River (state of São Paulo, Brazil) from June 2008 to May 2009. (Olig, oligotrophic; Temp, temperature; EC, electrical conductivity; DO, dissolved oxygen; Transp, transparency; TN, total nitrogen; TP, total phosphorus; Chl, chlorophyll; TSI, trophic state index).

\begin{tabular}{|c|c|c|c|c|c|c|c|c|c|}
\hline Reservoirs & $\begin{array}{l}\text { Temp } \\
\left({ }^{\circ} \mathrm{C}\right)\end{array}$ & $\mathrm{pH}$ & $\begin{array}{c}\mathrm{EC} \\
\left(\mu \cdot \mathrm{cm}^{-1}\right)\end{array}$ & $\begin{array}{c}\text { DO } \\
\left(\mathrm{mg}^{-1} \mathrm{~L}^{-1}\right)\end{array}$ & $\begin{array}{c}\text { Transp } \\
\text { (m) }\end{array}$ & $\begin{array}{c}\mathrm{TN} \\
\left(\mu \mathrm{g} \cdot \mathrm{L}^{-1}\right)\end{array}$ & $\begin{array}{c}\mathrm{TP} \\
\left(\mu \mathrm{g} \cdot \mathrm{L}^{-1}\right)\end{array}$ & $\begin{array}{c}\mathrm{Chl} a \\
\left(\mu \mathrm{g} . \mathrm{L}^{-1}\right)\end{array}$ & TSI \\
\hline Barra Bonita & $22.1 \pm 2.1$ & $6.2 \pm 0.8$ & $219.7 \pm 40.8$ & $3.3 \pm 2.0$ & $4.6 \pm 1.7$ & $2000.0 \pm 690.0$ & $94.2 \pm 41.8$ & $18.3 \pm 31.8$ & Eutr \\
\hline Bariri & $22.9 \pm 2.5$ & $6.8 \pm 0.9$ & $206.1 \pm 40.8$ & $4.8 \pm 2.3$ & $5.0 \pm 1.5$ & $1937.9 \pm 412.5$ & $91.2 \pm 41.4$ & $22.7 \pm 31.3$ & Eutr \\
\hline Ibitinga & $23.2 \pm 2.5$ & $6.3 \pm 0.5$ & $169.7 \pm 35.2$ & $5.3 \pm 2.4$ & $5.9 \pm 2.3$ & $1445.1 \pm 327.6$ & $79.5 \pm 68.5$ & $10.3 \pm 11.5$ & Meso \\
\hline Nova Avanhandava & $24.0 \pm 2.4$ & $6.7 \pm 0.6$ & $162.7 \pm 11.1$ & $5.8 \pm 2.5$ & $2.3 \pm 1.1$ & $681.5 \pm 97.8$ & $40.0 \pm 18.6$ & $10.2 \pm 13.3$ & Olig \\
\hline
\end{tabular}

at most sites in September 2008 and January 2009. The mean total contents for the year of study were $681.5 \mu \mathrm{g}$ $\mathrm{L}^{-1} \pm 97.8 \mu \mathrm{g} \mathrm{L}^{-1}$ for $\mathrm{N}$ and $40.0 \mu \mathrm{g} \mathrm{L}^{-1} \pm 18.6 \mu \mathrm{g} \mathrm{L}^{-1}$ for $\mathrm{P}$. The chlorophyll $a$ levels were highly variable during the months of study and the mean was $1.87 \pm 0.93 \mu \mathrm{g} \mathrm{L}^{-1}$ in May 2009 and $24.99 \pm 21.5 \mu \mathrm{g} \mathrm{L}^{-1}$ in July 2008, the overall mean being $10.2 \pm 13.3 \mu \mathrm{g} \mathrm{L}^{-1}$ (Tab. III). In general, the calculated TSI showed the Nova Avanhandava reservoir to be oligotrophic (Tab. III) with a slight tendency to become mesotrophic in certain months.

In the mid Tietê basin (the first three reservoirs

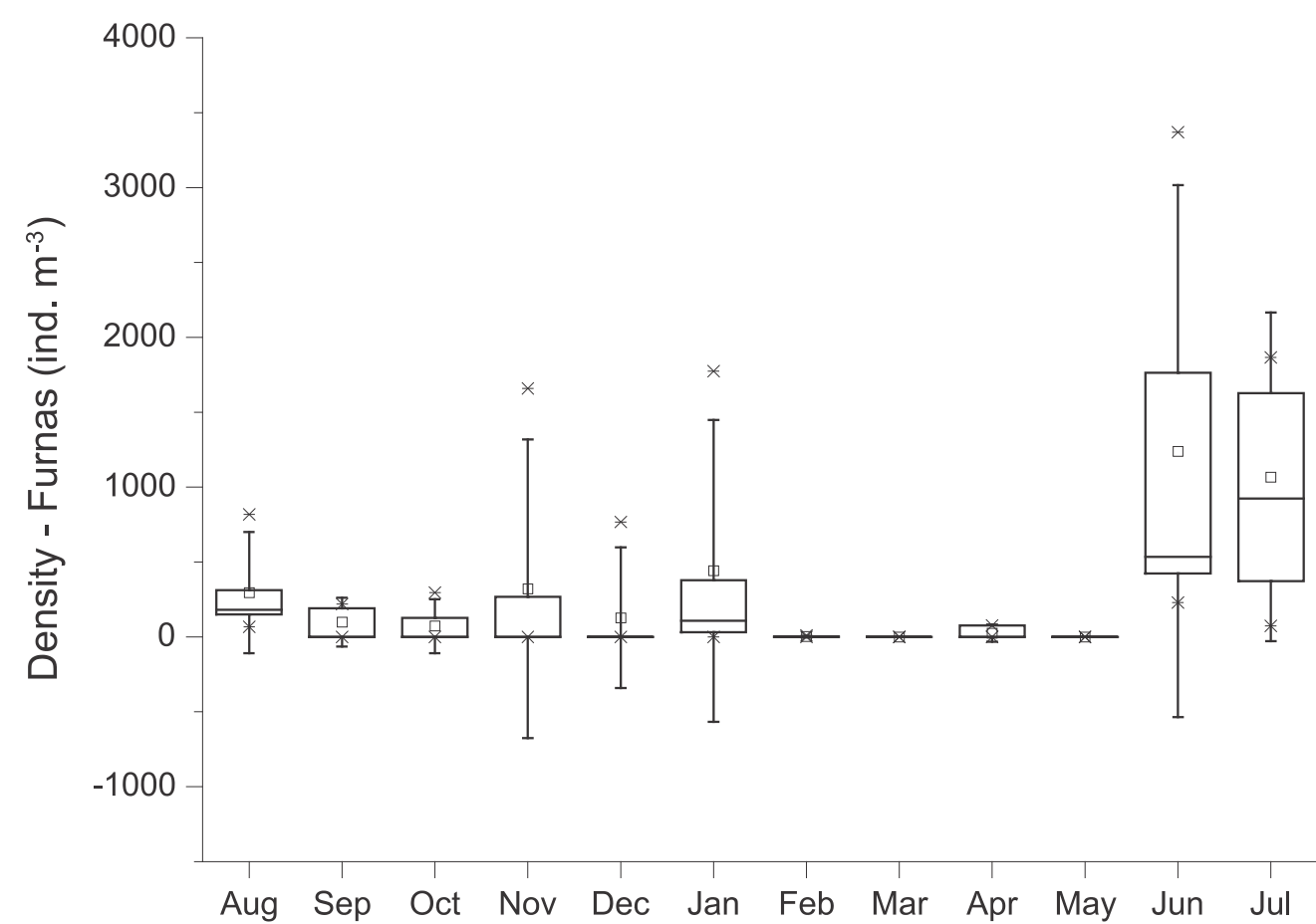

Fig. 1. Mean monthly density of the Synchaeta jollyae (Shiel \& Koste, 1993) (Rotifera, Synchaetidae) population in the Furnas reservoir, state of Minas Gerais, Brazil, from August 2006 to July 2007. in Tab. III) S. jollyae was found in all samples in June 2008, in Barra Bonita and Bariri in September and only Bariri reservoir in May 2009 (Tab. IV). In the lower reaches (Nova Avanhandava reservoir), this species was identified only in June 2008. In fact, by far the highest densities occurred at all sites in June 2008, when temperatures were lower and the water varied in trophic status from site to site (oligo, meso and eutrophic conditions were observed). The overall maximum density found in this drainage basin was 132,777 ind $\mathrm{m}^{-3}$ in the Bariri reservoir. 
Tab. IV. Changes in Synchaeta jollyae (Shiel \& Koste, 1993) densities (ind. $\mathrm{m}^{-3}$ ) in each of the Mid-low Tietê reservoirs (state of São Paulo, Brazil), from June 2008 to May 2009.

\begin{tabular}{ccccc}
\hline \multicolumn{5}{c}{ Mid-low Tietê River basin } \\
\hline & Barra Bonita & Bariri & Ibitinga & $\begin{array}{c}\text { Nova } \\
\text { Avanhandava }\end{array}$ \\
\hline Jun & 953 & 132,777 & 7,364 & 1,200 \\
Sep & 167 & 148 & 0 & 0 \\
Jan & 0 & 0 & 0 & 0 \\
May & 0 & 143 & 0 & 0 \\
\hline
\end{tabular}

Statistical analysis. Population abundances in both systems (Furnas and Tietê reservoirs) showed statistically significant differences between the summer (rainy) and winter (dry) periods (Tab. V). sampled for decades, opening the possibility that it could be a newcomer. The globalization of biodiversity, with invasive species arriving from various continents, is also a possibility.

Wherever these populations of $S$. jollyae might have originated, it appears to be a species well established and adapted to a wide range of conditions in the neotropics. It will be worth checking whether it has or will reach a much wider distribution in South American freshwaters.

Acknowledgments. To the Brazilian research Foundations CAPES and $\mathrm{CNPq}$ and to the Hydrobiology and Hatchery Station of FURNAS Centrais Elétricas S. A., P\&D Aneel Program, Contract \#017138 for the financial support.

Tab. V. Means and standard deviations of water temperature and densities of Synchaeta jollyae (Shiel \& Koste, 1993) in Furnas (state of Minas Gerais, Brazil) and Mid-low Tietê (state of São Paulo, Brazil) reservoirs, and $p$-values (Mann-Whitney) $\left({ }^{*} p \leq 0.05\right.$; Temp, temperature).

\begin{tabular}{|c|c|c|c|c|}
\hline & \multicolumn{2}{|c|}{ Furnas } & \multicolumn{2}{|c|}{ Tietê } \\
\hline & $\begin{array}{c}\text { Mild Temp }\left({ }^{\circ} \mathrm{C}\right) \\
(23.08 \pm 2.12)\end{array}$ & $\begin{array}{c}\text { High Temp }\left({ }^{\circ} \mathrm{C}\right) \\
(26.47 \pm 1.78)\end{array}$ & $\begin{array}{c}\text { Mild Temp }\left({ }^{\circ} \mathrm{C}\right) \\
(20.96 \pm 0.68)\end{array}$ & $\begin{array}{c}\text { High Temp }\left({ }^{\circ} \mathrm{C}\right) \\
(25.14 \pm 1.28)\end{array}$ \\
\hline S. jollyae (ind. $\mathrm{m}^{-3}$ ) & $455 \pm 743$ & $165 \pm 414$ & $17.826 \pm 46.513$ & $18 \pm 50$ \\
\hline$p$ (Mann-Whitney) & \multicolumn{2}{|c|}{$0.006^{*}$} & \multicolumn{2}{|c|}{$0.007 *$} \\
\hline
\end{tabular}

\section{DISCUSSION}

Southeast Brazil is characterized by two well-defined climatic seasons, namely a cooler dry winter and a hot rainy summer, resulting in great changes in abiotic and biotic conditions of aquatic ecosystems, especially in large reservoirs. Several authors (Reynolds, 1984; SMith, 1986; Hwang et al., 2003) have already shown evidence of the important role environmental factors play in controlling the structure and dynamics of plankton communities. In many tropical reservoirs, the zooplankton communities undergo great changes in abundance and a noticeable seasonal species succession

In the studied reservoirs, $S$. jollyae was abundant and appeared at all times around the year, although its highest population densities occurred at lower temperatures. It is likely that its distribution is correlated with mildly warm waters. According to Rougier et al. (2000), Synchaeta species generally tolerate relatively cool temperatures as in the north Mediterranean. It is probable that at the mild temperatures of tropical winter outperforms this species has better performance than other rotifer and cladoceran competitors.

The occurrence of this rotifer seems to be independent of the trophic status of the freshwater habitat, as it has been found in reservoirs of contrasting trophic states.

It is not yet possible to tell whether $S$. jollyae is a widely distributed species that has been overlooked in previous plankton studies in South America. It is however intriguing that it has not been noticed in the reservoirs under study which have been regularly

\section{REFERENCES}

AdDINSOFt. 2009. XLSTAT version 2009.6.01. New York, Addinsoft USA

Golterman, H. L.; Clymo, R. S. \& Ohnstad, M. A. M. 1978. Methods for physical and chemical analysis of freshwaters. 2ed. Oxford, Blackwell Scientific Publications. 213p.

HwanG, D. W.; Kim, G.; LeE, Y. W. \& YANG, H. S. 2003. Measurement of 224Ra and 223Ra in the Nakdong River estuary and the South Sea of Korea. Journal of the Korean Society of Oceanography 38:80-86

LORENZEN, C. J. 1966. A method for the continuous measurement of in vivo chlorophyll concentration. Deep Sea Research and Oceanographic 13:223-227.

Mackereth, F. J. H; Heron, J. \& TAlling, J. F. 1978. Water analysis: some revised methods for limnologists. New York, Freshwater Biological Association. 117p.

Negreiros, N. F.; Santos, R. M.; Silva, L. C.; Rocha, O. \& Santos WisNiEWSKi, M. J. 2011. First record of Synchaeta jollyae (Shiel \& Koste, 1993) (Rotifera) in the Neotropical region: Furnas Reservoir, MG, Brazil. Brazilian Journal of Biology 71:227-228.

Nogrady, T. \& Segers, H. 2002. Rotifera 6. The Asplanchnidae, Gastropodidae, Lindiidae, Microcodinidae, Synchaetidae, Trochosphaeridae. In: DumONT, H. J. ed. Guides to the Identification of the Microinvertebrates of the Continental Waters of the World 18. Dordrecht, Backhuys Publishers BV. p.1-264.

Pinto-Coelho, R. M. \& Corgosinho, P. H. 1998. Changes in the structure of zooplankton in response to a trophic gradient in Furnas reservoir, Minas Gerais. In: VIII Seminário de Ecologia, Anais... São Carlos, Universidade Federal de São Carlos. p. $1173-1188$

Reynolds, C. S. 1984. The ecology of freshwater phytoplankton. 1ed. Cambridge, Cambridge University Press. 384p.

Rougier, C.; Pourriot, R. \& Lam-Hoai, T. 2000. The genus Synchaeta (rotifers) in a north-western Mediterranean coastal lagoon (Etang de Thau, France): taxonomical and ecological remarks. Hydrobiologia 436:105-117.

Shiel, R. J. \& Koste, W. 1993. Rotifera from Australian waters. IX. Gastropodidae, Synchaetidae, Asplanchnidae (Rotifera: Monogononta). Transactions of the Royal Society South Australia 117:111-139.

Sмiтн, M. E. 1986. Distribution Patterns and Seasonal Occurrence of Rhabdostyla sp. on Dero nivea (Oligochaeta, Naididae). The American Midland Naturalist 116:348-355. 